\title{
PEMODELAN JUMLAH PENDUDUK MISKIN DI JAWA TENGAH MENGGUNAKAN GEOGRAPHICALLY WEIGHTED REGRESSION (GWR)
}

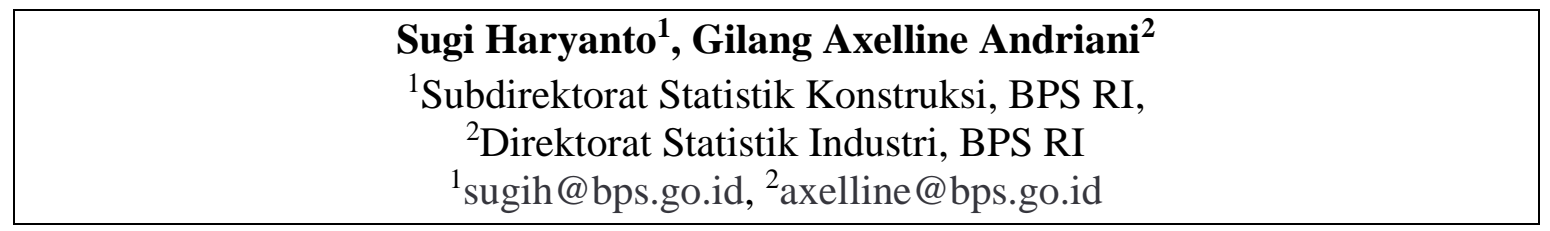

Diterima: Agustus 2019; Disetujui: November 2019

\begin{abstract}
Poverty is something that is often a measure of the success of a regional head's leadership. It is also the first goal of Sustainable Development Goals (SDG's) to be alleviated. The right policy is very important to be made for the achievement of sustainable development goals. Geographically Weighted Regression (GWR) modeling is important to be used to develop models in each district / city as a basis for policy makers. The variables used in this study are the number of poor people, Human Development Index (HDI), unemployment rate (TPT), and regency/municipality minimum wage (UMK). The purpose of this study is to determine the factors that influence the number of poor people in each regency/municipality in Central Java. GWR modeling is more effective in describing the number of poor people in regencies/municipalities in Central Java in 2018. This is indicated by the increase in the value of $R^{2}$ and the decrease in the value of Root Mean Square Error (RMSE) and Mean Absolute Percentage Error (MAPE).
\end{abstract}

Keyword: GWR, Poverty, SDG's.

Abstraksi. Kemiskinan merupakan sesuatu yang sering menjadi ukuran keberhasilan kepemimpinan seorang kepala daerah. Selain itu juga sebagai tujuan pertama Sustainable Development Goals (SDG's) untuk dientaskan. Kebijakan yang tepat sangat penting dibuat demi tercapainya tujuan pembangunan berkelanjutan. Pemodelan Geographically Weighted Regression (GWR) penting digunakan untuk menyusun model di setiap kabupaten/kota sebagai dasar pembuat kebijakan. Tujuan penelitian ini yaitu menentukan faktor-faktor yang berpengaruh terhadap jumlah penduduk miskin di setiap kabupaten/kota di Jawa Tengah. Peubah yang digunakan dalam penelitian ini yaitu jumlah penduduk miskin, Indeks Pembangunan Manusia (IPM), Tingkat Pengangguran Terbuka (TPT), dan Upah Minimum Kabupaten/kota (UMK). Pemodelan GWR lebih efektif dalam menggambarkan jumlah penduduk miskin di kabupaten/kota di Jawa Tengah tahun 2018. Hal ini ditunjukkan dengan adanya peningkatan nilai $R^{2}$ serta penurunan nilai Root Mean Square Error (RMSE) dan Mean Absolute Percentage Error (MAPE).

Kata kunci: GWR, Kemiskinan, SDG's.

\section{PENDAHULUAN}

Jawa Tengah merupakan salah satu provinsi dengan jumlah penduduk miskin terbanyak, ke-2 menurut hasil Survei Sosial Ekonomi Nasional (SUSENAS) September 2018 (BPS, 2019). Jumlah penduduk miskin di Jawa Tengah sebanyak 3.867,42 ribu orang atau setara dengan $15,06 \%$ dari jumlah penduduk miskin di Indonesia. Kemiskinan merupakan tujuan pertama dalam tujuan pembangunan berkelanjutan atau Sustainable Development Goals (SDG's) yaitu mengentaskan segala bentuk kemiskinan di manapun (UCLG, 2015). Dalam rangka mencapai tujuan SDG's tersebut tentunya diperlukan strategi dan kebijakan yang tepat oleh setiap pemerintah daerah. Kebijakan tersebut bisa tepat sasaran ketika dapat mengetahui faktorfaktor yang mempengaruhinya. 
Indeks Pembangunan Manusia (IPM) merupakan indikator penting untuk mengukur keberhasilan dalam upaya membangun kualitas hidup manusia (BPS, 2018). Penelitian Susanti (2013) menunjukkan bahwa kenaikan IPM dapat menurunkan kemiskinan di Jawa Barat. Fadlillah et al. (2016) memberikan kesimpulan yang sama bahwa IPM berpengaruh negatif dan signifikan terhadap tingkat kemiskinan. Hasil ini dikuatkan oleh penelitian Prasetyoningrum dan Sukmawati (2018) bahwa IPM signifikan berpengaruh terhadap kemiskinan dengan arah negatif.

Tingkat Pengangguran Terbuka (TPT) merupakan persentase banyaknya pengangguran dibanding jumlah angkatan kerja (BPS, 2019a). Berdasarkan penelitian Ningrum (2017) berpengaruh signifikan dengan arah positif terhadap kemiskinan. Penelitian Siburian (2017) menghasilkan kesimpulan yang sejalan bahwa TPT memberikan pengaruh yang positif dan signifikan terhadap kemiskinan di Sumatera Utara. Hal yang sama ditunjukkan oleh penelitian Agustina etal. (2018) bahwa TPT berpengaruh positif dan signifikan.

Upah Minimum Kabupaten/kota (UMK) adalah upah bulanan terendah yang terdiri dari upah pokok termasuk tunjangan tetap. Hasil penelitian Octasari (2016) menunjukkan bahwa UMK memiliki pengaruh negatif dan signifikan terhadap kemiskinan. Kurniawati et al. (2017) dalam penelitian menyimpulkan hal yang senada bahwa UMK memberikan pengaruh negatif dan signifikan. Penelitian Sutikno et al. (2019) menguatkan kesimpulan bahwa UMK berpengaruh signifikan terhadap kemiskinan.

Model regresi merupakan salah satu model statistika yang sering digunakan untuk mengetahui hubungan antara peubah tak bebas dengan peubah bebasnya. Pada data yang objeknya dalam bentuk wilayah dimungkinkan adanya keragaman antar wilayah. Menurut Fotheringham et al. (1996) dan Brunsdon et al. (1996), diperlukan suatu model berbasis kewilayahan untuk mengatasi keragaman antar wilayah yang disebut heterogenitas spasial. Salah satu model spasial yang digunakan untuk mengatasi keragaman antar wilayah yaitu Geographically Weighted Regression (GWR) (Fotheringham et al., 2002). Peubah tak bebas jumlah penduduk miskin diukur di setiap kabupaten/kota yang berdimensi wilayah sehingga dimungkinkan menggunakan model GWR. Model GWR menggunakan unsur matriks pembobot spasial W yang besarnya tergantung pada kedekatan antar lokasi. Semakin dekat suatu lokasi, bobot pengaruhnya akan semakin besar. Fungsi pembobot yang digunakan untuk GWR dalam tulisan ini adalah fungsi Kernel Exponential.

Penelitian ini menggunakan data berbasis wilayah pada $35 \mathrm{kabupaten/kota} \mathrm{di}$ Jawa Tengah tahun 2018, sehingga dimungkinkan menggunakan model GWR. Manfaat dari penelitian ini yaitu memberikan informasi kepada pemerintah kabupaten/kota di Jawa Tengah mengenai pemodelan faktor yang mempengaruhi jumlah penduduk miskin. Sehingga pemerintah kabupaten/kota dapat membuat kebijakan masing-masing yang lebih tepat untuk mengatasi jumlah penduduk miskin sebagaimana tujuan SDG's. Tujuan dari penelitian ini yaitu menentukan faktorfaktor yang berpengaruh terhadap jumlah penduduk miskin di setiap kabupaten/kota di Jawa Tengah menggunakan pendekatan model spasial (model GWR). 
METODE PENELITIAN

Penelitian ini menggunakan data sekunder yaitu data jumlah penduduk miskin sebagai peubah tak bebas dan tiga peubah bebas, yaitu IPM, TPT, dan UMK.
Cakupan data penelitian adalah 35 kabupaten/kota di Jawa Tengah tahun 2018. Peubah-peubah yang digunakan dalam penelitian ini dapat dilihat pada Tabel 1.

Tabel 1.

Rincian Peubah yang Digunakan pada Data Sekunder

\begin{tabular}{lll}
\hline \multicolumn{1}{c}{ Peubah } & \multicolumn{1}{c}{ Satuan } & \multicolumn{1}{c}{ Sumber Data } \\
\hline Jumlah penduduk miskin / Y & Ribu jiwa & BPS \\
Indeks pembangunan manusia (IPM) $/ \mathrm{X}_{1}$ & Persen & BPS \\
Tingkat pengangguran terbuka (TPT) $/ \mathrm{X}_{2}$ & Persen & BPS \\
Upah minimum kabupaten/kota (UMK) $/ \mathrm{X}_{3}$ & Ribu rupiah & SK Gubernur Jawa Tengah \\
\hline
\end{tabular}

Sumber: BPS dan SK Gubernur Jawa Tengah

\section{Model Regresi Linier}

Model regresi linier merupakan metode untuk memodelkan hubungan antara peubah respon dan peubah penjelas. Model regresi linier untuk $p$ peubah penjelas secara umum ditulis sebagai berikut:

$y_{i}=\beta_{0}+\sum_{k=1}^{p} \beta_{k} x_{i k}+\varepsilon_{i}$

dengan $i=1,2, \ldots, n ; \beta_{0}, \beta_{1}, \ldots, \beta_{p}$ adalah parameter model dan $\varepsilon_{1}, \varepsilon_{2}, \ldots, \varepsilon_{n}$ adalah error yang diasumsikan identik, independen, dan berdistribusi normal dengan rata-rata nol dan ragam konstan $\sigma^{2}$ atau $\left(\varepsilon_{i} \sim \operatorname{IIDN}\left(0, \sigma^{2}\right)\right)$.

Pendugaan parameter regresi menggunakan metode kuadrat terkecil (MKT) atau Ordinary Least Squares (OLS). Pengujian parameter model regresi secara simultan menggunakan pendekatan distribusi $\mathrm{F}$ dan secara parsial menggunakan pendekatan distribusi $t$ (Rencher, 2007).

Model Geographically Weighted Regression (GWR)

$\begin{array}{ccr}\text { Model } & \text { Geographically } & \text { Weighted } \\ \text { Regression } & (\mathrm{GWR}) & \text { adalah }\end{array}$

pengembangan dari model regresi dimana parameter dihitung pada setiap lokasi pengamatan, sehingga setiap lokasi pengamatan mempunyai nilai parameter yang berbeda-beda (Fotheringham et al., 1998). Peubah tak bebas $y$ dalam model GWR diprediksi dengan peubah bebas yang masingmasing koefisien regresinya tergantung pada lokasi dimana data tersebut diamati (Lu et al. 2011). Model GWR dapat ditulis sebagai berikut:

$y_{i}=\beta_{0}\left(u_{i}, v_{i}\right)+\sum_{k=1}^{p} \beta_{k}\left(u_{i}, v_{i}\right) x_{i k}+\varepsilon_{i}$

dengan $\left(u_{i}, v_{i}\right)$ adalah koordinat latitude dan longitude dari suatu lokasi geografis ke-i, $\beta_{k}$ adalah nilai koefisien parameter ke-k $(\mathrm{k}=1, \ldots, \mathrm{p}), x_{i k}$ adalah peubah penjelas ke-k pada lokasi ke-i $(i=1,2, \ldots, n)$.

Pendugaan parameter model GWR dilakukan dengan metode Weighted Least Square (WLS) yaitu dengan memberikan pembobot spasial untuk mewakili letak data observasi satu dengan lainnya. Formula pendugaan parameter dirumuskan sebagai berikut:

$\widehat{\beta}\left(u_{i}, v_{i}\right)=\left[\boldsymbol{X}^{T} \boldsymbol{W}\left(u_{i}, v_{i}\right) \boldsymbol{X}\right]^{-1} \boldsymbol{X}^{T} \boldsymbol{W}\left(u_{i}, v_{i}\right) \boldsymbol{y}$ 
dimana $\boldsymbol{W}\left(u_{i}, v_{i}\right)$ adalah matriks berukuran $n \times n$ dengan diagonal pembobot spasial pada lokasi ke-i.

Formula pembobot spasial yang digunakan dalam penelitian ini yaitu fungsi kernel Bisquare. $w_{i j}=$ $\left[1-\left(\frac{d_{i j}}{b}\right)^{2}\right]^{2}$ dengan $d_{i j}$ adalah jarak Euclideanantara lokasi $\left(u_{i}, v_{i}\right)$ ke lokasi $\left(u_{j}, v_{j}\right), b$ adalah parameter non negatif yang diketahui dan biasanya disebut parameter penghalus (bandwidth). Untuk mendapatkan bandwidth optimum, dapat dilakukan dengan menghitung cross validation $(\mathrm{CV})$ sehingga didapat $\mathrm{CV}$ yang minimum (Fotheringham et al. 2002) dengan menggunakan rumus sebagai berikut :

$C V=\sum_{i=1}^{n}\left[y_{i}-\hat{y}_{\neq i}(b)\right]^{2}$

\section{Perbandingan Model}

Perbandingan model regresi linier dan model GWR dilakukan untuk mengetahui model mana yang lebih baik diterapkan untuk menggambarkan jumlah penduduk miskin di Jawa Tengah tahun 2018. Kriteria kebaikan model yang digunakan untuk membandingkan ketiga model tersebut yaitu nilai koefisien determinasi $\left(\mathrm{R}^{2}\right)$, Root Mean Square Error (RMSE), dan Mean Absolute Percentage Error (MAPE). Model terbaik adalah model dengan nilai $\mathrm{R}^{2}$ terbesar dan RMSE serta MAPE yang terkecil.

\section{HASIL DAN PEMBAHASAN \\ Deskripsi}

Hasil penduga parameter dan uji parsial peubah penjelas model regresi jumlah penduduk miskin kabupaten/kota di Jawa Tengah tahun 2018 dapat dilihat pada Tabel 2. Tabel tersebut menunjukkan bahwa tidak semua peubah bebas berpengaruh nyata terhadap jumlah penduduk miskin di Jawa Tengah pada taraf nyata $5 \%$. Nilai $\mathrm{R}^{2}$ yang dihasilkan model ini sebesar 0,4135 dan $\mathrm{R}^{2}$ adjusted sebesar 0,3567 .

Tabel 2.

Penduga Parameter Regresi Linier dengan 3 Peubah Bebas

\begin{tabular}{llll}
\hline Peubah & Koefisien & Galat baku & Nilai-p \\
\hline $\mathrm{X}_{1}$ & $-9,4879$ & 2,2503 & $0,0002 *$ \\
$\mathrm{X}_{2}$ & 5,0998 & 5,3929 & 0,3516 \\
$\mathrm{X}_{3}$ & 0,0026 & 0,0059 & 0,6534 \\
\hline \multicolumn{4}{c}{ Keterangan: * nyata pada $\alpha$ 5\% } \\
& Sumber: Hasil Olah Data, 2019
\end{tabular}

Nilai koefisien korelasi antar peubah yang memiliki nilai korelasi rendah tertera pada Tabel 3. Hanya peubah bebas terhadap jumlah penduduk miskin yaitu TPT yang memiliki arah korelasi positif. TPT $\left(\mathrm{X}_{2}\right)$ dengan nilai korelasi sebesar Nilai koefisien korelasi tertinggi sebesar - 0,167.

0,627 yaitu peubah IPM $\left(\mathrm{X}_{1}\right)$. Peubah bebas

Tabel 3.

Nilai Koefisien Korelasi Antar Peubah

\begin{tabular}{llll}
\hline & Jumlah penduduk miskin & IPM & TPT \\
\hline IPM & $-0,627$ & & \\
TPT & 0,167 & $-0,061$ & \\
UMK & $-0,229$ & 0,451 & $-0,043$ \\
\hline
\end{tabular}

Sumber: Hasil Olah Data, 2019 
Uji multikolinieritas dilakukan untuk mengetahui adanya korelasi di antara peubah-peubah penjelas yang digunakan. Uji ini menggunakan dengan menghitung nilai VIF (Variance Inflation Factor). Nilai VIF yang kurang dari 5 menunjukkan bahwa tidak terdapat multikolinieritas pada peubah penjelas yang dipakai. Tabel 4 memperlihatkan bahwa nilai VIF peubah penjelas kurang dari 5, sehingga dapat disimpulkan bahwa tidak terdapat multikolinieritas pada semua peubah penjelas yang dipakai dalam penelitian ini.

Tabel 4.

Nilai VIF (Variance Inflation Factor) Peubah Bebas

\begin{tabular}{llll}
\hline & IPM & TPT & UMK \\
\hline VIF & 1.257 & 1.004 & 1.255 \\
\hline
\end{tabular}

Sumber: Hasil Olah Data, 2019

\section{Uji Heterogenitas Spasial}

Uji heterogenitas diperlukan dalam rangka mengetahui adanya keragaman spasial pada pengamatan (Fotheringham et al. 2002), dengan statistik uji yang digunakan yaitu Breusch-Pagan. Nilai uji Breusch-Pagan yang dihasilkan yaitu sebesar 11,413 dengan derajat bebas 3 dan nilai-p sebesar 0,0097. Berdasarkan nilai-p tersebut, model signifikan pada taraf nyata 5 persen, sehingga dapat dikatakan adanya heterogenitas spasial data jumlah penduduk miskin kabupaten/kota di Jawa Tengah tahun 2018.

\section{Matriks Pembobot Spasial}

Matriks pembobot yang digunakan dalam penelitian ini adalah fungsi pembobot Fixed Exponential yang menghasilkan lebar jendela yang sama di setiap lokasi. Penentuan bandwidth optimum dilakukan dengan menghitung nilai CV (Cross Validation) yang terkecil. $\mathrm{CV}$ terkecil yang dihasilkan yaitu sebesar 112844,1 dengan nilai bandwidth spasial $\left(b_{S}\right)$ sebesar 0,42003. Artinya, jarak maksimum daerah yang masih terpengaruh oleh karakteristik suatu daerah sejauh 0,42003 derajat atau $46,9982 \mathrm{~km}$.

\section{Penduga parameter model GWR}

Deskripsi penduga parameter menggunakan model GWR digambarkan pada Tabel 5. Penduga parameter intersep pada lokasi pengamatan jumlah penduduk miskin di Jawa Tengah berkisar antara 490,246 hingga 1171,992 ribu jiwa. Peubah bebas IPM memiliki nilai negatif di seluruh wilayah kabupaten/kota di Jawa Tengah, artinya ketika IPM meningkat di suatu wilayah maka akan menurunkan jumlah penduduk miskin di wilayah tersebut. Peubah bebas TPT dan UMK bervariasi pada setiap lokasi, artinya bahwa di wilayah tertentu perubahan kedua peubah bebas akan menurunkan jumlah penduduk miskin, di wilayah lain justru akan meningkatkan. Tabel tersebut juga menggambarkan bahwa secara rataan pengaruhnya seperti pada model regresi linier, namun ada sebagian kabupaten/kota yang tidak sejalan dengan rataannya. 
Tabel 5.

Ringkasan Koefisien Penduga Model GWR

\begin{tabular}{lllll}
\hline Peubah & Minimum & Maksimum & Rataan & Standar deviasi \\
\hline Intersep & 490,246 & 1171,992 & 704,851 & 188,039 \\
IPM & $-18,217$ & $-6,081$ & $-9,354$ & 3,112 \\
TPT & $-8,948$ & 23,679 & 2,182 & 8,672 \\
UMK & $-0,003$ & 0,012 & 0,003 & 0,003 \\
\hline
\end{tabular}

Sumber: Hasil Olah Data, 2019

Perbandingan statistik kebaikan model menurunkan RMSE dan MAPE, artinya antara regresi linier dan GWR berdasarkan nilai keragaman sisaan yang dihasilkan nilai $\mathrm{R}^{2}$, Root Mean Square Error (RMSE), semakin kecil sehingga menghasilkan dan Mean Absolute Percentage Error pendugaan yang mendekati dengan data (MAPE). Dapat dilihat bahwa pemodelan sebenarnya.

GWR mampu meningkatkan nilai $\mathrm{R}^{2}$ juga

Tabel 6.

Perbandingan Model

\begin{tabular}{llll}
\hline Metode & $\mathrm{R}^{2}$ & RMSE & MAPE \\
\hline Regresi linier & 0,4135 & 49,0371 & 67,3931 \\
GWR & 0,7711 & 30,6329 & 40,8103 \\
\hline
\end{tabular}

Sumber: Hasil Olah Data, 2019

\section{Pengujian Parameter Model GWR}

Peubah-peubah bebas yang memiliki pengaruh terhadap peubah tak bebas untuk tiap kabupaten/kota dapat dilihat dari hasil pengujian parameter model GWR. Setiap kabupaten/kota faktor-faktor yang berpengaruhnya berbeda disebabkan adanya perbedaan karakteristik dari setiap kabupaten/kota. Perbedaan ini meliputi dari segi geografis, fasilitas umum, fasilitas sosial, hingga pemerintahan. Perbedaan faktor yang mempengaruhi memungkinkan tiap kabupaten/kota untuk membuat kebijakan yang sesuai dengan kondisi dan kebutuhan di daerah masing-masing dalam rangka mengurangi jumlah penduduk miskin.

$$
\text { Pengelompokan kabupaten/kota }
$$
berdasarkan faktor-faktor yang berpengaruh menggunakan model GWR digambarkan pada Gambar 1. Pada model GWR terdapat tiga kelompok yang terbentuk. Kelompok pertama yaitu kabupaten/kota yang jumlah penduduk miskinnya dipengaruhi oleh IPM $\left(\mathrm{X}_{1}\right)$ saja. Kelompok kedua yaitu kabupaten/kota yang jumlah penduduk miskinnya dipengaruhi oleh IPM $\left(\mathrm{X}_{1}\right)$ dan TPT $\left(\mathrm{X}_{2}\right)$. Kelompok ketiga kabupaten/kota yang semua peubah bebas yang digunakan tidak berpengaruh signifikan terhadap jumlah penduduk miskinnya. 


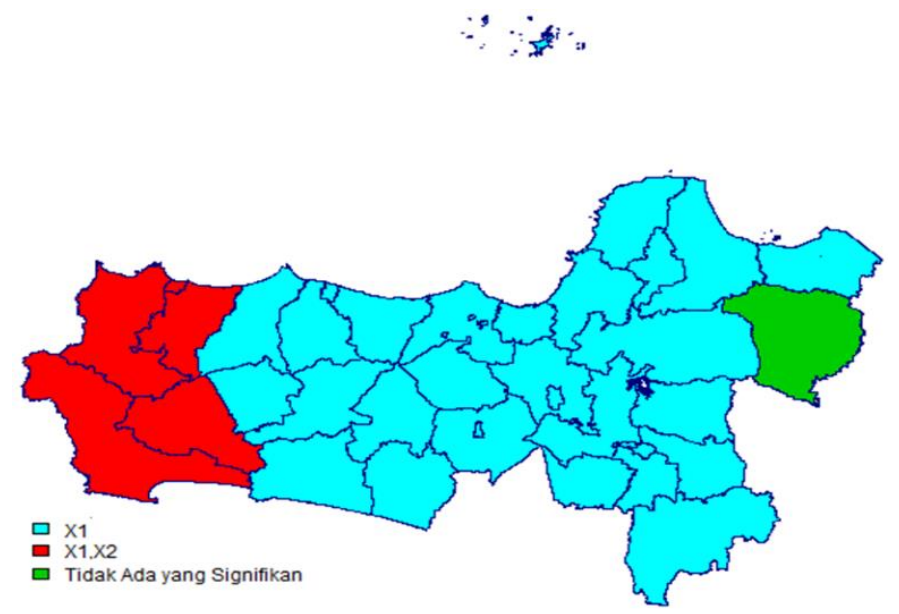

Gambar 1. Peta Berdasarkan Faktor-Faktor yang Berpengaruh Terhadap Jumlah Penduduk Miskin Di Jawa Tengah Tahun 2018

Sumber: Hasil Olah Data, 2019

Rincian pengelompokan wilayah dipengaruhi oleh peubah bebas IPM $\left(\mathrm{X}_{1}\right)$. kabupaten/kota berdasarkan faktor yang Sedangkan peubah bebas UMK $\left(\mathrm{X}_{3}\right)$ tidak berpengaruh disajikan pada Tabel 7. Tabel berpengaruh di semua kabupaten/kota di tersebut menunjukkan bahwa hampir Jawa Tengah.

seluruh kabupaten/kota di Jawa Tengah

Tabel 7.

Pengelompokan Kabupaten/Kota Berdasarkan Faktor-Faktor yang Berpengaruh

\begin{tabular}{ll}
\hline Peubah berpengaruh & Nama kabupaten/kota \\
\hline & Purbalingga, Banjarnegara, Kebumen, Purworejo, Wonosobo, \\
& Magelang, Boyolali, Klaten, Sukoharjo, Wonogiri, Karanganyar, \\
& Sragen, Grobogan, Rembang, Pati, Kudus, Jepara, Demak, \\
& Semarang, Temanggung, Kendal, Batang, Pekalongan, \\
& Pemalang, Kota Magelang, Kota Surakarta, Kota Salatiga, Kota \\
& Semarang, Kota Pekalongan \\
\hline $\mathrm{X}_{1}$ dan $\mathrm{X}_{2}$ & Cilacap, Banyumas, Tegal, Brebes, Kota Tegal \\
\hline Tidak ada & Blora \\
\hline
\end{tabular}

Sumber: Hasil Olah Data, 2019

\section{Pemeriksaan asumsi model GWR Asumsi Kenormalan Sisaan}

Gambar 2 menunjukkan bahwa asumsi kenormalan sisaan model GWR sudah terpenuhi, terlihat dari q-q plot normal yang menunjukkan bahwa data berada di sekitar garis normal. Apabila dilihat berdasarkan hasil uji kenormalan shapiro-wilk nilainya 0,974 dengan nilai-p 0,571 yang artinya sudah memenuhi asumsi dari pemodelan. 


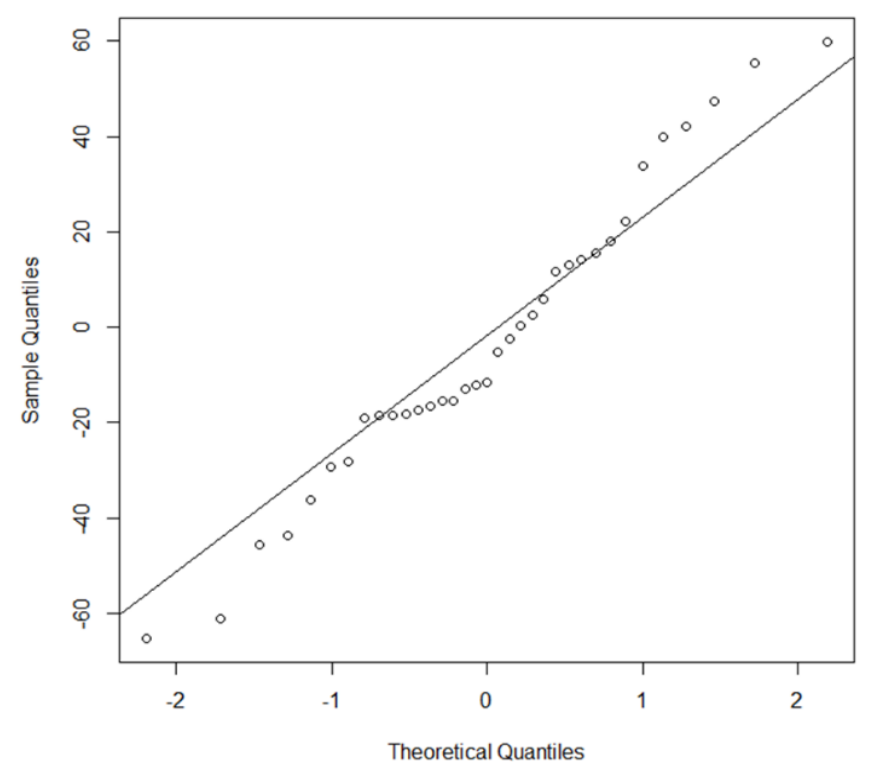

Gambar 2. Normal Q-Q plot sisaan model GWR

Sumber: Hasil Olah Data, 2019

\section{Asumsi Nonautokorelasi Sisaan}

Pemeriksaan otokorelasi dilakukan dengan melihat plot sisaan terhadap kabupaten/kota. Gambar 3 menunjukkan bahwa pola sisaan berdasarkan kabupaten/kota terlihat acak. Sehingga keseluruhan dapat disimpulkan bahwa asumsi nonautokorelasi antara sisaan terpenuhi.

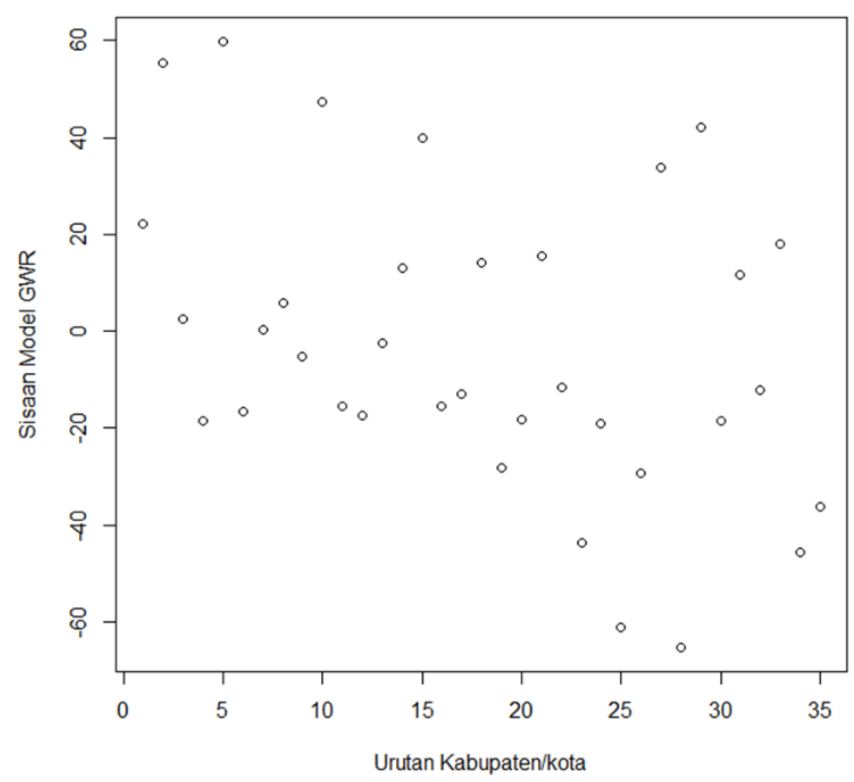

Gambar 3. Plot sisaan berdasarkan kabupaten/kota dari model GWR

Sumber: Hasil Olah Data, 2019

\section{Interpretasi model GWR}

Model GWR menghasilkan nilai penduga parameter yang berbeda-beda di setiap lokasi. Pada model GWR, masing- masing peubah memberikan pengaruh yang berbeda. Begitu pula besaran nilai koefisien parameternya juga berbeda-beda di setiap kabupaten/kota. 
Sebagai contoh model GWR Kota Pekalongan adalah sebagai berikut:

$\hat{y}=832.8809-9.9195 x_{1}+2.7762 x_{2}-0.0025 x_{3}$

sedangkan untuk model Kabupaten Sragen adalah sebagai berikut:

$\hat{y}=588,1015-7,0557 x_{1}-3,7403 x_{2}+0,0025 x_{3}$

Kedua persamaan tersebut memperlihatkan perbedaan antara model GWR Kota Pekalongan dengan Kabupaten Sragen. Peubah yang signifikan pada Kota Pekalongan maupun Kabupaten Sragen adalah peubah IPM $\left(\mathrm{X}_{1}\right)$ saja, sedangkan peubah bebas lainnya tidak signifikan. Nilai koefisien determinasi untuk model Kota Pekalongan sebesar 77,22 persen dan Kabupaten Sragen sebesar 76,28 persen. Pada model GWR Kota Pekalongan dan Kabupaten Sragen, $\mathrm{X}_{1}$ memiliki pengaruh nyata dan negatif terhadap jumlah penduduk miskin, bedanya nilai pengaruh yang lebih kecil untuk Kabupaten Sragen. Peubah $\mathrm{X}_{2}$ pada Kota Pekalongan dan Kabupaten Sragen sama-sama tidak berpengaruh nyata, namun beda arah pengaruhnya. Hal ini menunjukkan bahwa peubah penjelas yang sama memberikan pengaruh yang berbeda pada setiap kabupaten/kota. Secara keseluruhan, model GWR jumlah penduduk miskin di Jawa Tengah tahun 2018 menghasilkan nilai $\mathrm{R}^{2}$ sebesar 77,11 persen. Sehingga kebijakan yang tepat untuk Kota Pekalongan dan Kabupaten Sragen yaitu berfokus pada peningkatan nilai IPM-nya, terutama menyasar pada indikator-indikator penyusun nilai IPM.

\section{SIMPULAN}

Berdasarkan penelitian yang telah dilakukan, dapat diambil kesimpulan bahwa pemodelan GWR lebih efektif dalam menggambarkan jumlah penduduk miskin di kabupaten/kota di Jawa Tengah tahun 2018. Hal ini ditunjukkan dengan adanya peningkatan nilai $\mathrm{R}^{2}$ serta penurunan nilai RMSE dan MAPE yang mengindikasikan nilai dugaan lebih mendekati nilai aktual. Hasil penelitian ini dapat dimanfaatkan dalam pengambilan kebijakan yang bersifat lokal berdasarkan faktor-faktor yang berpengaruh di wilayah tersebut.

Penelitian ini belum memperhatikan pencilan (outlier) yang dalam pemodelan menggunakan regresi yang sensitif terhadap pencilan. Oleh sebab itu, ke depan lebih dikembangkan lagi menggunakan regresi robust untuk mengatasi pencilan yang ada di beberapa lokasi. Penelitian ke depan juga bisa menggunakan regresi panel spasial untuk membuat kebijakan setiap lokasi dengan mempertimbangkan perubahan antar waktu.

\section{DAFTAR PUSTAKA}

Agustina, E, Syechalad, M.N. \& Hamzah, A. (2018). Pengaruh Jumlah Penduduk, Tingkat Pengangguran dan Tingkat Pendidikan terhadap Kemiskinan di Provinsi Aceh. Jurnal Perspektif Ekonomi Darussalam. 4(2). 265-283.

[BPS] Badan Pusat Statistik. (2018). Indeks Pembangunan Manusia 2017. Jakarta (ID): Badan Pusat Statistik.

[BPS] Badan Pusat Statistik. (2019a). Keadaan Angkatan Kerja di Indonesia: Februari 2019. Jakarta (ID): Badan Pusat Statistik.

[BPS] Badan Pusat Statistik. (2019b). Profil Kemiskinan di Indonesia September 2018. Berita Resmi Statistik. Diunduh pada 25 Agustus 2019, dari https://www.bps.go.id/pressrelease.html? 
Brunsdon, C, Fotheringham, A.S., dan Charlton, ME. (1996). Geographical Weighted Regression: A Method for Exploring Spatial Nonstationerity. Geographical Analysis. 28(4). 281-298.

Fadlillah, N, Sukiman, \& Dewi, A.S. (2016). Analisis Pengaruh Pendapatan Perkapita, Tingkat Pengangguran, IPM dan Pertumbuhan Penduduk terhadap Kemiskinan di Jawa Tengah Tahun 2009-2013. Eko-Regional. 11(1). 18-26.

Fajriyah, N \& Rahayu, S.P. (2016). Pemodelan Faktor-Faktor yang Mempengaruhi Kemiskinan Kabupaten/Kota di Jawa Timur Menggunakan Regresi Data Panel. Jurnal Sains dan Seni ITS. 5(1). 45-50.

Fotheringham, A.S., Charlton, M.E., dan Brunsdon, C. (1996) The geography of parameter space: an investigation of spatial non-stationarity. International Journal of Geographical Information Science. 10(5). 605-627.

Fotheringham, A.S., Charlton, M.E., dan Brunsdon, C. (1998) Geographically weighted regression: a natural evolution of the expansion method for spatial data analysis. Environment and Planning A. 30. 1905-1927.

Fotheringham, AS, Brunsdon, C, dan Charlton, ME. (2002) Geographical Weighted Regression: The Analysis of Spatially Varying Relationship. Chichester: John Wiley\& Sons Ltd.

Kurniawati, A, Gunawan, B.T., \& Indrasari, D.P.R. (2017). Dampak Upah Minimum terhadap Kemiskinan di Indonesia Tahun 2006-2014. Journal Of Research in Economics and Management. 17(2). 233-252.

Lu, B, Charlton M, \&Fotheringham, A.S. (2011). Geographically Weighted Regression Using a Non-Euclidean Distance Metric with a Study on London House Price Data. Procedia Environmental Sciences. 7. 92-97.

Ningrum, S.S. (2017). Analisis Pengaruh Tingkat Pengangguran Terbuka, Indeks Pembangunan Manusia, dan Upah Minimum terhadap Jumlah Penduduk Miskin di Indonesia Tahun 2011-2015. Jurnal Ekonomi Pembangunan. 15(2). 184-192.

Prasetyoningrum, A.K. \& Sukmawati, U.S. (2018). Analisis Pengaruh Indeks Pembangunan Manusia (IPM), Pertumbuhan Ekonomi, dan Pengangguran terhadap Kemiskinan di Indonesia. Equilibrium: Jurnal Ekonomi Syariah. 6(2). 217-240.

Rencher, A.C. \&Schaalje, G.B. (2007) Linear Models in Statistics. 2nd ed. New York (US): John Wiley \& Sons Ltd.

Siburian, E. M. (2017). Analisis Faktor yang Mempengaruhi Tingkat Kemiskinan di Provinsi Sumatera Utara. INA-Rxiv. 1-6.

Susanti, S. (2013). Pengaruh Produk Domestik Regional Bruto, Pengangguran dan Indeks Pembangunan Manusia terhadap Kemiskinan di Jawa Barat dengan Menggunakan Analisis Data Panel. Jurnal Matematika Integratif. 9(1). 1-18.

Sutikno, R.Y., Rotinsulu, C.H., \&Tumangkeng, S.Y.L. (2019). Pengaruh Upah Minimum dan Investasi terhadap Kemiskinan di Provinsi Sulawesi Utara. Jurnal Berkala Ilmiah Efisiensi. 19(1). 88-98.

[UCLG] United Citiesand Local Governments. (2015). Tujuan Pembangunan Berkelanjutan yang Perlu Diketahui oleh Pemerintah Daerah. Jakarta (ID): United Citiesand Local Governments Asia Pasific. 